\title{
Control of globe fringerush (Fimbristylis miliacea) and selectivity to rice crop irrigated with bispyribac-sodium + metsulfuron-methyl associated with adjuvants
}

\author{
Controle de cominho (Fimbristylis miliacea) e seletividade à cultura do arroz \\ irrigado com bispyribac-sodium + metsulfuron-methyl associados a adjuvantes
}

\author{
Tadeu Tormena', Marcos Massuo Kashiwaqui ${ }^{1}$, Cleber Daniel de Goes Maciel ${ }^{1 *}$, João Igor de Souza ${ }^{2}$, \\ Carlos Rafael Brandalize Soares², Ricardo Ângelo Deparis Pivatto², Enelise Osco Helvig², \\ André Augusto Pazinato da Silva², Ricardo André Kloster Karpinski
}

\begin{abstract}
This study aimed to evaluate the control of globe fringerush (Fimbristylis miliacea) and selectivity to rice crop irrigated with an in-tank mixture of bispyribac-sodium + metsulfuron-methyl associated with adjuvants. The experiment was conducted in the municipality of Douradina, Paraná state, Brazil (2312'32.0" South, 5317'39.9" West), in the agricultural year of 2012/2013. An experimental randomized complete block design with ten treatments and four replications was used. The treatments consisted of applying an in-tank mixture of the herbicides bispyribac-sodium + metsulfuron-methyl at two doses $(32+1.3$ and $\left.40+3.3 \mathrm{~g}^{\text {ai }} \mathrm{ha}^{-1}\right)$ associated with the adjuvants Iharaguen ${ }^{\mathrm{TM}}$ (375 mL.ha $\left.{ }^{-1}\right)$, Orobor N1 ${ }^{\mathrm{TM}}\left(75 \mathrm{~mL} \cdot \mathrm{ha}^{-1}\right)$, LI $700^{\mathrm{TM}}\left(150 \mathrm{~mL} \cdot \mathrm{ha}^{-1}\right)$ and TA $35^{\mathrm{TM}}\left(50 \mathrm{~mL} \cdot \mathrm{ha}^{-1}\right)$, as well as weeded and unweeded control. Although the effectiveness of globe fringerush (F. miliacea) control with the in-tank mixture of the herbicides bispyribac-sodium + metsulfuron-methyl associated with Iharaguen ${ }^{\mathrm{TM}}$ and Orobor $\mathrm{N}^{\mathrm{TM}}$ has been significantly higher than the effectiveness of these herbicides associated with LI $700^{\mathrm{TM}}$ and TA $35^{\mathrm{TM}}$, there were no significant differences among the treatments in terms of selectivity and grains yield of the rice cultivar Epagri 108.
\end{abstract}

KEYWORDS: Oryza sativa L.; weed; herbicide; application technology.
RESUMO: O objetivo deste trabalho foi avaliar o controle de cominho (Fimbristylis miliacea) e a seletividade à cultura do arroz irrigado com a mistura em tanque de bispyribac-sodium + metsulfuron-methyl associada a adjuvantes. Conduziu-se o experimento no município de Douradina (2312'32,0" Sul, 5317’39,9” Oeste), PR, no ano agrícola 2012/2013. O delineamento experimental utilizado foi o de blocos completos casualizados com dez tratamentos e quatro repetiçóes. Os tratamentos foram constituídos pela aplicação da mistura em tanque dos herbicidas bispyribac-sodium + metsulfuron-methyl, em duas doses $(32+1,3$ e 40+3,3 g i.a. ha-1 $)$, e com adjuvantes Iharaguen ${ }^{\circ}$ (375 mL.ha-1), Orobor N1" (75 mL.ha $\left.{ }^{-1}\right)$, LI $700^{\circ}(150$ mL.ha-1) e TA $35^{\circ}$ (50 mL.ha $\left.{ }^{-1}\right)$, assim como de testemunha capinada e sem capina. Apesar de a eficácia de controle de cominho (F. miliacea) com a mistura em tanque de bispyribac-sodium + metsulfuron-methyl associada aos adjuvantes Iharaguen e Orobor N1 ${ }^{\circ}$ ter sido significativamente superior ao LI $700^{\circ}$ e TA $35^{\circ}$, não foram constatadas diferenças significativas entre os tratamentos em termos de seletividade e produtividade de grãos para o cultivar de arroz Epagri 108.

PALAVRAS-CHAVE: Oryza sativa L.; planta daninha; herbicida; tecnologia de aplicação. 


\section{INTRODUCTION}

Rice crop, especially the irrigated one, has a high economic importance in the states of Rio Grande do Sul and Santa Catarina, in which there is a high rice productivity, reaching means of 6.7 and 7.0 t.ha $^{-1}$, respectively. However, despite being grown with high technical standards, each year rice producers have faced weed management problems, constituting one of the most costly and laborious procedures in rice production (FLECK et al., 2008).

Fimbristylis miliaceae (L.) Vahl, popularly known as globe fringerush, is an herbaceous annual or perennial plant which is reproduced by seeds although it forms clumps. It is an erect plant with height ranging from 30 to $50 \mathrm{~cm}$. This species is found throughout Brazil, especially in irrigated rice fields, in which it rapidly settles as dense populations, thereby increasing production costs due to its difficult control. This species still settles in irrigation and drainage canals, reservoirs and backwaters of hydroelectric plants (Moreira; BRAGANÇA, 2010; Lorenzi, 2014). According to Schons (2009), plant lodging is the main damage this species causes to the irrigated rice crop, affecting its production and mechanized harvesting.

OrTIZ et al. (2012), in a dose-response study, identified ten pyrazosulfuron-ethyl resistant populations of $F$ miliaceae collected in irrigated rice fields in the state of Guárico, Venezuela. In Brazil, Schaedler et al. (2013) also reported the occurrence of $F$. miliaceae, in the state of Santa Catarina, infesting irrigated rice crop, presenting cross-resistance to the herbicides pyrazosulfuron-ethyl, penoxsulam, bispyribac-sodium, and ethoxysulfuron, being all of them acetolactate synthase (ALS) enzyme inhibitors.

According to Ferreira et al. (2008), weeds often have a competitive advantage over those plants grown in agricultural ecosystems, since genetic breeding programs have developed small cultivars with little vegetative growth, but with high accumulation of plant parts of economic interest. In this context, nature acts on weeds selecting these plants to make them more and more efficient, whereas the man has domesticated grown plants removing their competitive aggressiveness (VAsConcelos et al., 2012).

FLECK et al. (2004) mentioned that weed infestation is the main limiting factor in irrigated rice yield, and, in the total absence of control, losses may exceed $85 \%$ of grain production. Currently, chemical control using herbicides is the most used method by the majority of rice producers to control weeds in irrigated rice crop, due to its high efficiency, practicality of use (Andres; Machado, 2004; Concenço et al., 2006) and economy (Erasmo et al., 2004; FLECK et al., 2008).

However, for the successful application of herbicide, the procedures indicated on their labels should be followed carefully. Among the various factors of technology application, the use of adjuvants added to the spray mixture during their preparation is one of the most important methods. QUeIroz et al. (2008) reported that these substances are used to overcome plant mechanism against the penetration of pesticides, with the ability to modify the activity of the applied products and the pulverization characteristics, increasing the application efficiency. For VARGas; Roman (2006), these substances added to the formulation or herbicide mixture modify certain properties of the solution, to facilitate the application or minimize potential problems.

This study aimed to evaluate the control of globe fringerush (F. miliacea) and selectivity to rice crop irrigated with an in-tank mixture of the herbicides bispyribac-sodium + metsulfuron-methyl associated with adjuvants.

\section{MATERIAL AND METHODS}

The experiment was conducted in the municipality of Douradina (Paraná state, Brazil), located at the geographic coordinates: Latitude 2312'32.0" South, Longitude 5317'39.9” West, at a mean altitude of $245 \mathrm{~m}$. The region's climate is classified as humid subtropical (Cfa), according to Köeppen, i.e., a mesothermal humid subtropical climate, with hot summers, infrequent frosts, trend of rainfall concentrated in the summer, and without a dry season (CAviglione et al., 2000).

The soil of the experimental area is classified as typical eutrophic Melanic Gleisol (EMBrapa, 2013) and showed the $\mathrm{pH}$ of 4.80 (in $\mathrm{CaCl}_{2}$ ), $5.35 \mathrm{cmol} \mathrm{dm}^{-3}$ of $\mathrm{H}^{+}+\mathrm{Al}^{+3}, 10.63 \mathrm{cmol}_{\mathrm{c}} \mathrm{dm}^{-3}$ of $\mathrm{Ca}^{+2}, 2.97 \mathrm{cmol}_{\mathrm{c}} \mathrm{dm}^{-3}$ of $\mathrm{Mg}^{+2}, 0.22 \mathrm{cmol}_{\mathrm{c}} \mathrm{dm}^{-3}$ of $\mathrm{K}^{+}$, $15.12 \mathrm{mg} \mathrm{dm}^{-3}$ of P, $25.29 \mathrm{~g} \mathrm{dm}^{-3}$ of M.O, $48.0 \%$ sand, $8.0 \%$ silt, and $44.0 \%$ clay.

Sowing of irrigated rice (cultivar Epagri 108) was carried out on October 29, 2012, using as base fertilization $275 \mathrm{~kg} \mathrm{ha}^{-1}$ of formulated 15-15-15 Nitrogen-PhosphorusPotassium (NPK), and throwing sowing density of approximately 600 seeds $\mathrm{m}^{-2}$. Topdressing was split into two applications, one of $100 \mathrm{~kg} \mathrm{ha}^{-1}$ of urea and another of $120 \mathrm{~kg} \mathrm{ha}^{-1}$ of formulated 30-00-20 (NPK). Maintenance applications consisted of two applications of the fungicides tricyclazole

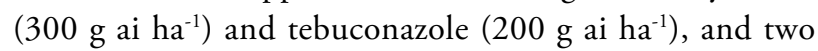
applications of the insecticide cypermethrin (100 $\left.\mathrm{g} \mathrm{ai} \mathrm{ha}^{-1}\right)$ to control caterpillars.

The assay was conducted from October 29, 2012 to March 17, 2013. It was used an experimental randomized complete block design with ten treatments and four replications. The experimental units consisted of plots with $4.0 \mathrm{~m}$ wide $\times 5.0 \mathrm{~m}$ length $\left(20.0 \mathrm{~m}^{2}\right)$, and as the control group, it was left a band of $1 \mathrm{~m}$ to the right side of all plots without application (Fig. 1).

The treatments were constituted by an in-tank mixture of the herbicides bispyribac-sodium + metsulfuron-methyl, at two doses, and associated with different adjuvants, as well as weeded and unweeded control groups (Table 1). 
The herbicide treatment was performed in post-emergence in the late afternoon on February 12, 2012, a week before the water goes into the retention terrace, using a backpack sprayer with constant pressure based on $\mathrm{CO}_{2}$, equipped with a bar with six nozzles (TTi 110015 ) spaced $0.5 \mathrm{~m}$ above the crop canopy, and working pressure of $40 \mathrm{lb} \mathrm{pol}^{-2}$, which provided a spray volume of $200 \mathrm{~L} \mathrm{ha}^{-1}$ (Fig. 1). The climatic conditions (relative air humidity, temperature, and wind speed), during the treatment applications, were monitored by a portable digital thermo-hygro-anemometer. At the moment of application, there were no clouds, the soil was moist, and on average relative air humidity, temperature, and wind speed of $62.4 \%, 27.6^{\circ} \mathrm{C}$, and $0.45 \mathrm{~km} \mathrm{~h}^{-1}$, respectively. At this time, the rice cultivar Epagri 108 was at 5 and 6 leaves stage, and the infestation consisted of globe fringerush $(F$ miliacea) at 3 to 5 leaves stage, and a mean density of 76 plants per $\mathrm{m}^{-2}$.

The $\mathrm{pH}$ of the herbicidal solutions was evaluated with a digital bench $\mathrm{pH}$ meter, and the static surface tension was estimated by the gravimetric method, using a precision scale and a graduated burette, in which the mass of droplets, formed

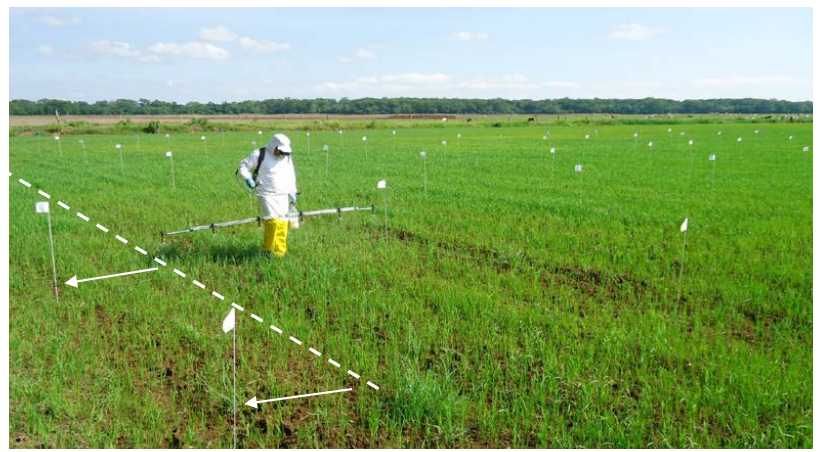

Figure 1. Schematic representation of the application of herbicide treatments in irrigated rice crop, and the control area (a band of $1 \mathrm{~m}$ to the right side of all plots) without application in the experimental units. at the end of the burette, was determined between 25 and 30 seconds, according to the method described by Maciel et al. (2010).

The evaluated characteristics were: globe fringerush control percentage at 7, 14, 21, 28, and 42 days after application (DAA), based on a visual injury scale ranging from 0 (no plant injuries) to $100 \%$ (plant death) (SBCPD, 1995), phytointoxication of irrigated rice crop (at 7, 14, 28 and 42 DAA) using the European Weed Research Council (EWRC) scale (1964) ranging from 1 (no injuries in the crop) to 9 (death of plants), grains yield ( $\mathrm{kg} \mathrm{ha}^{-1}$ ), corrected to $14 \%$ moisture; and the physicochemical characteristics of the herbicidal solutions, surface tension, and $\mathrm{pH}$.

The data regarding the control and productivity of irrigated rice crop were subjected to analysis of variance by F-test, and the means compared by the Scott-Knott grouping test (1974), at 5\% probability level. The comparison among the surface tension values of the solutions was performed using the confidence interval for differences between means, at 5\% probability (confidence interval of $95 \%-95 \% \mathrm{CI}$ ).

\section{RESULTS AND DISCUSSION}

With regards the physicochemical characteristics, all treatments significantly reduced the static surface tension and $\mathrm{pH}$ of the herbicide solutions (Fig. 2). The results regarding the association of Iharaguen ${ }^{\mathrm{TM}}$ and Orobor $\mathrm{N} 1^{\mathrm{TM}}$ with the in-tank mixture of bispyribac-sodium + metsulfuron-methyl were similar as the $\mathrm{pH}$ levels; these treatments most reduced the surface tension, although they did not differ among themselves, by comparing the studied doses. Concerning the TA $35^{\mathrm{TM}}$, despite the $\mathrm{pHs}$ of the solutions have been next to those obtained with Iharaguen $^{\mathrm{TM}}$ and Orobor $\mathrm{N}^{\mathrm{TM}}$, the surface tension reduction

Table 1. Treatments and their dosages of herbicides and adjuvants used in irrigated rice crop control globe fringerush (Fimbristylis miliacea).

\begin{tabular}{|c|c|c|c|}
\hline Treatments & $\begin{array}{c}\text { Doses herbicides } \\
\quad(\mathrm{g} \text { ai ha-1) }\end{array}$ & Adjuvants & 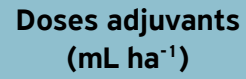 \\
\hline 1. bispyribac-sodium ${ }^{\prime 1}+$ metsulfurom-methy/ ${ }^{/ 2}$ & $32+1.3$ & Iharaguen $^{\mathrm{TM} / 3}$ & 375 \\
\hline 2. bispyribac-sodium + metsulfurom-methyl & $40+3.3$ & Iharaguen $^{\text {TM }}$ & 375 \\
\hline 3. bispyribac-sodium + metsulfurom-methyl & $32+1.3$ & Orobor $\mathrm{N} 1^{\mathrm{TM} / 4}$ & 75 \\
\hline 4. bispyribac-sodium + metsulfurom-methyl & $40+3.3$ & Orobor $\mathrm{N} 1^{\mathrm{TM}}$ & 75 \\
\hline 5. bispyribac-sodium + metsulfurom-methyl & $32+1.3$ & LI $700^{\mathrm{TM} / 5}$ & 150 \\
\hline 6. bispyribac-sodium + metsulfurom-methyl & $40+3.3$ & $\mathrm{LI} 700^{\mathrm{m}}$ & 150 \\
\hline 7. bispyribac-sodium + metsulfurom-methyl & $32+1.3$ & $\mathrm{TA}-35^{\mathrm{TM} / 6}$ & 50 \\
\hline 8. bispyribac-sodium + metsulfurom-methyl & $40+3.3$ & $\mathrm{TA}-35^{\mathrm{MM}}$ & 50 \\
\hline 9. without weed control & - & - & - \\
\hline 10. with weed control & - & - & - \\
\hline
\end{tabular}

'bispyribac-sodium: Nominee $400 \mathrm{SC}^{\mathrm{m}}\left(400 \mathrm{~g} . \mathrm{L}^{-1}\right) ;{ }^{2}$ metsulfuron-methyl: Ally $\mathrm{y}^{\mathrm{m}}\left(600 \mathrm{~g} . \mathrm{kg}^{-1}\right) ;{ }^{/ 3}$ polyoxyethylene alkylphenyl ether; ${ }^{/ 4}$ orange peel oil; ${ }^{15}$ mixture of lecithin and propionic acid; ${ }^{16}$ sodium lauryl ether sulphate. 
was significantly lower than those found for Iharaguen ${ }^{\mathrm{TM}}$ and Orobor $\mathrm{N1}^{\mathrm{TM}}$, and higher than the reduction observed in the treatment with LI $700^{\mathrm{TM}}$, especially at the higher dose of the intank mixture of herbicide. Treatment with LI $700^{\mathrm{TM}}$ had the lowest surface tension reductions in comparison to the other adjuvants. However, it showed the lowest $\mathrm{pH}$ levels $(\mathrm{pH} 4.0$ approximately).

Miller and Butler Ellis (2000) reported that changes in the properties of the sprayed solution, caused by the addition of adjuvants, can influence both the formation process of droplets and the behavior of the mixture in contact with the target. Similarly, the addition of adjuvants to spray mixtures can incite interactions among the applied products significantly increasing their performance, such as a higher rate of absorption and/or translocation (MARTINs et al., 2009), as well as negatively affect the result of the application (RYCKAERT et al., 2007; QueIroz et al., 2008).

In a combined analysis of globe fringerush ( $F$. miliacea) control levels, it was verified that the in-tank mixture of the herbicides bispyribac-sodium + metsulfuron-methyl promoted unsatisfactory results up to $7 \mathrm{DAA}(\leq 80 \%)$ in all treatments, and the highest values in this period occurred with the associated with the adjuvants LI $700^{\mathrm{TM}}$ and TA $35^{\mathrm{TM}}$ (Table 2). However, at $14 \mathrm{DAA}$, treatments evolved to excellent levels

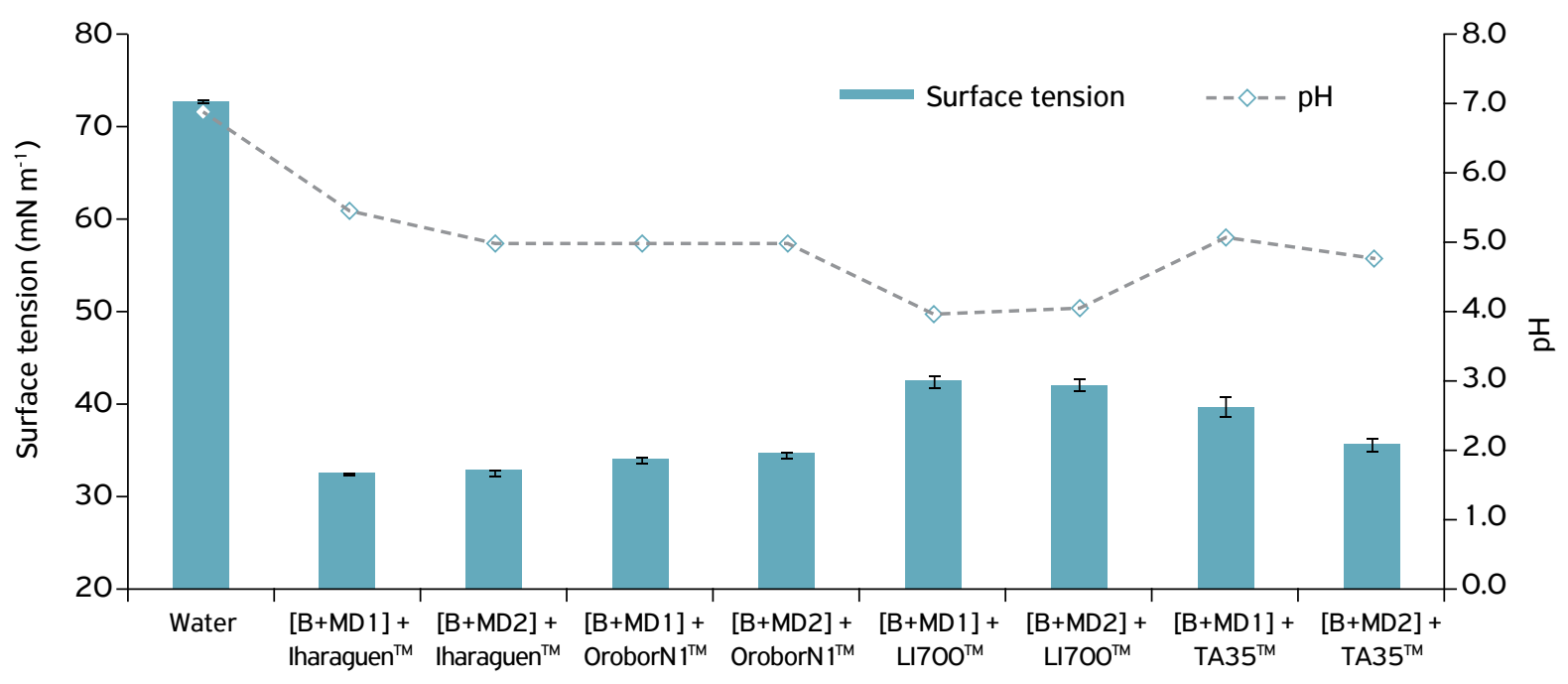

Figure 2. Static surface tension (confidence interval between means \pm IC 95\%) and pHs of the in tank mixtures of bispyribac-sodium + metsulfuron-methyl $[B+M]$ applied in post-emergence of irrigated rice crop, at different doses and adjuvants.

Table 2. Control percentage of globe fringerush (Fimbristylis miliacea) using the in-tank mixture of bispyribac-sodium + metsulfuronmethyl $[B+M]$ applied in post-emergence of irrigated rice crop, at different doses and adjuvants.

\begin{tabular}{|c|c|c|c|c|c|c|c|c|c|c|c|}
\hline \multirow{2}{*}{$\begin{array}{l}\text { Treatments } \\
\text { 1. }[B+M]^{/ 2}+\text { Iharaguen }^{\mathrm{TM} / 3}\end{array}$} & \multirow{2}{*}{$\begin{array}{c}\text { Doses } \\
{[\text { g ai ha-1 }]+\left[\mathrm{mL} \mathrm{ha}^{-1}\right]} \\
{[32+1.3]+[375]}\end{array}$} & \multicolumn{2}{|c|}{$7 \mathrm{DAA}^{\prime 1}$} & \multicolumn{2}{|c|}{14 DAA } & \multicolumn{2}{|c|}{21 DAA } & \multicolumn{2}{|c|}{28 DAA } & \multicolumn{2}{|c|}{42 DAA } \\
\hline & & 22.8 & C & 87.8 & C & 96.5 & $\mathrm{~B}$ & 97,8 & $A$ & 99,3 & A \\
\hline 2. $[B+M]+$ Iharaguen $^{\mathrm{TM}}$ & {$[40+3.3]+[375]$} & 19.5 & $\mathrm{C}$ & 92.5 & B & 99.0 & $A$ & 99,5 & $A$ & 100,0 & $A$ \\
\hline 3. $[B+M]+$ Orobor $N 1^{T M / 4}$ & {$[32+1.3]+[75]$} & 19.0 & C & 90.3 & B & 98.3 & A & 99,5 & A & 99,8 & A \\
\hline 4. $[B+M]+$ Orobor $N 1^{1 M}$ & {$[40+3.3]+[75]$} & 20.8 & $\mathrm{C}$ & 91.0 & B & 97.3 & $A$ & 99,5 & $A$ & 99,5 & $A$ \\
\hline 5. $[B+M]+\mathrm{LI} 700^{T M / 5}$ & {$[32+1.3]+[150]$} & 28.3 & B & 86.0 & C & 93.5 & B & 93,8 & B & 93,3 & C \\
\hline 6. $[B+M]+L I 700^{m}$ & {$[40+3.3]+[150]$} & 29.0 & B & 90.8 & B & 95.8 & B & 95,8 & B & 95,3 & $\mathrm{~B}$ \\
\hline 7. $[B+M]+T A 35^{T M / 6}$ & {$[32+1.3]+[50]$} & 26.5 & B & 90.3 & B & 93.3 & B & 95,0 & B & 92,8 & C \\
\hline 8. $[B+M]+T A 35^{T M}$ & {$[40+3.3]+[50]$} & 25.8 & B & 93.5 & B & 96.0 & B & 95,8 & B & 95,5 & B \\
\hline 9. Without weed control & - & 0.0 & $\mathrm{D}$ & 0.0 & D & 0.0 & C & 0,0 & $\mathrm{C}$ & 0,0 & D \\
\hline 10. With weed control & - & 100.0 & A & 100.0 & A & 100.0 & A & 100,0 & A & 100,0 & A \\
\hline Fcal & - & \multicolumn{2}{|c|}{$166.461^{*}$} & \multicolumn{2}{|c|}{$540.060^{*}$} & \multicolumn{2}{|c|}{$715.991^{*}$} & \multicolumn{2}{|c|}{$2957.665^{*}$} & \multicolumn{2}{|c|}{$1513.429 *$} \\
\hline CV (\%) & - & \multicolumn{2}{|c|}{13.95} & \multicolumn{2}{|c|}{3.05} & \multicolumn{2}{|c|}{2.63} & \multicolumn{2}{|c|}{1.30} & \multicolumn{2}{|c|}{1.81} \\
\hline
\end{tabular}

Means followed by the same letter in column do not differ statistically from each other by the Scott-Knott grouping test ( $\leq \leq 0.05)$; *significant; ${ }^{1} D A A:$ days after application; ${ }^{\prime 2} \mathrm{~B}$ : bispyribac-sodium = Nominee $400 \mathrm{SC}^{8}\left(400 \mathrm{~g} \cdot \mathrm{L}^{-1}\right) ;{ }^{12} \mathrm{M}$ : metsulfuron-methyl = Ally $\left(600 \mathrm{~g} \cdot \mathrm{kg}^{-1}\right) ;{ }^{13}$ polyoxyethylene alkylphenyl ether; ${ }^{/ 4}$ orange peel oil; ${ }^{15}$ mixture of lecithin and propionic acid; ${ }^{16}$ sodium lauryl ether sulphate; Fcal: $\mathrm{F}$ calculated; CV (\%): coefficient of variation. 
of control, with efficiency higher than 90\%, except the lowest doses of the herbicides associated with the adjuvants Iharaguen $^{\mathrm{TM}}$ and LI $700^{\mathrm{TM}}$, which just had satisfactory efficiency, represented by $87.8 \%$ and $86.0 \%$ of control, respectively. At 21 and 28 DAA, the globe fringerush percentage control levels remained excellent, with a mean efficiency of 97.8 and $99.5 \%$ for Iharaguen ${ }^{\mathrm{TM}}$ and Orobor $\mathrm{N1}^{\mathrm{TM}}$, and 93.8 and $95.8 \%$ for LI $700^{\text {TM }}$ and TA $35^{\text {TM }}$, respectively. Although LI $700^{\text {TM }}$ and TA $35^{\text {TM }}$ have shown significantly lower values than the other adjuvants, they still have an excellent performance for the management of the studied weed species. The best results were obtained in the period up to 42 DAA with Iharaguen $^{\mathrm{Tm}}$ and Orobor $\mathrm{N}^{\mathrm{TM}}$, and the highest dose of the in-tank mixture of bispyribac-sodium + metsulfuron-methyl $\left(40+3.3 \mathrm{~g}\right.$ i ha $\left.{ }^{-1}\right)$, associated with the adjuvants LI $700^{\text {TM }}$ and TA $35^{\mathrm{TM}}$, presented better performance, compared to the lowest studied dose.

Sanchotene et al. (2007) found that water from the spray solution acidified at $\mathrm{pH} 4.5$ enhanced the effectiveness of the ALS-inhibiting herbicides imazethapyr + imazapic on red rice control (Oryza sativa). However, this response was not observed in the control of globe fringerush using the herbicides bispyribac-sodium + metsulfuron-methyl since the adjuvant LI $700^{\mathrm{TM}}$, although it has promoted the highest $\mathrm{pH}$ reduction in the solutions, did not stood out regarding efficiency.

It is noteworthy that to control globe fringerush in irrigated rice fields, the ALS enzyme inhibitor herbicides are among those mostly used in Brazil, and the first case of resistance of F. miliacea to this group of herbicides was detected in 2001 in the state of Santa Catarina (Noldin et al., 2002). Recently, studies developed in southern Brazil identified F. miliacea as a species with cross-resistance to the ALS-inhibiting herbicides bispyribac-sodium, ethoxysulfuron, pyrazosulfuron-ethyl, penoxsulam, imazethapyr, imazapic, and imazapyr (SosbaI, 2012; SChaedLer et al., 2013). In this sense, unlike this information, the results obtained in the present study with the in-tank mixture of bispyribac-sodium + metsulfuronmethyl, both ALS-inhibiting herbicides, did not characterize resistance behavior for this species in the studied population, and no information on the association of these herbicides was found in the literature, for comparison purposes. Therefore, even with the evidence of cross-resistance to ALS-inhibiting herbicides in southern Brazil, the high efficiency of globe fringerush control (Table 2) found here suggested the possibility of the evaluated population still be susceptible to this group of herbicides.

With regards to the rice cultivar Epagri 108 phytotoxicity (Table 3), it was found at 7 DAA just a slight chlorosis in the rice leaves, and no growth suppression was observed in the chemical treatments. At 14 DAA, no more visual symptoms were identified in the aerial part of the culture, compared to the one without application of the herbicides. For grains yield (Table 3), despite small differences in weed control efficiency, no formation of different mean groupings was noticed between chemical treatments and weeded control group, by the Scott and Knott test (1974) at 5\% probability. These results evidenced the crop selectivity to the in-tank mixture of bispyribac-sodium + metsulfuron-methyl, at their respective doses and used adjuvants, and mean reductions of 30.9 and $33.8 \%$

Table 3. Phytointoxication (European Weed Research Council - EWRC scale) and grains yield of irrigated rice crop (cultivar Epagri 108 ), subjected to the application, in post-emergence, of the in-tank mixture of bispyribac-sodium + metsulfuron-methyl [B + M].

\begin{tabular}{|c|c|c|c|c|c|c|}
\hline \multirow[t]{2}{*}{ Treatments } & \multirow{2}{*}{$\begin{array}{c}\text { Doses } \\
{[\mathrm{g} \text { ai ha-1 }]+\left[\mathrm{mL} \mathrm{ha}^{-1}\right]}\end{array}$} & \multicolumn{4}{|c|}{$\begin{array}{c}\text { Phytointoxication } \\
\text { (EWRC scale - Notes 1-9) }\end{array}$} & \multirow{2}{*}{$\begin{array}{c}\text { Grains yield } \\
\left(\mathrm{kg} \mathrm{ha}^{-1}\right)\end{array}$} \\
\hline & & $7 \mathrm{DAA}^{\prime 1}$ & 14 DAA & 28 DAA & 42 DAA & \\
\hline 1. $[B+M]^{/ 2}+$ Iharaguem ${ }^{T M / 3}$ & {$[32+1.3]+[375]$} & 2 & 1 & 1 & 1 & $7.410 .2 \mathrm{~A}$ \\
\hline 2. $[B+M]+$ Iharaguem $^{T M}$ & {$[40+3.3]+[375]$} & 2 & 1 & 1 & 1 & $7,470.5 \mathrm{~A}$ \\
\hline 3. $[B+M]+$ Orobor $N 1^{T M / 4}$ & {$[32+1.3]+[75]$} & 2 & 1 & 1 & 1 & $7,493.9 \mathrm{~A}$ \\
\hline 4. $[B+M]+$ Orobor $N 1^{\mathrm{TM}}$ & {$[40+3.3]+[75]$} & 2 & 1 & 1 & 1 & $7,390.9 \mathrm{~A}$ \\
\hline 5. $[B+M]+L I 700^{m / 5}$ & {$[32+1.3]+[150]$} & 2 & 1 & 1 & 1 & $7,682.2 \mathrm{~A}$ \\
\hline 6. $[B+M]+L I 700^{T M}$ & {$[40+3.3]+[150]$} & 2 & 1 & 1 & 1 & $7,590.1 \mathrm{~A}$ \\
\hline 7. $[B+M]+T A 35^{m / 6}$ & {$[32+1.3]+[50]$} & 2 & 1 & 1 & 1 & $7,643.4 \mathrm{~A}$ \\
\hline 8. $[B+M]+T A 35^{T M}$ & {$[40+3.3]+[50]$} & 2 & 1 & 1 & 1 & $7,363.6 \mathrm{~A}$ \\
\hline 9. Without weed control & - & 1 & 1 & 1 & 1 & $5,185.1 \mathrm{~B}$ \\
\hline 10. With weed control & - & 1 & 1 & 1 & 1 & $7,837.2 \mathrm{~A}$ \\
\hline Fcal & - & - & - & - & - & $2,324^{*}$ \\
\hline CV (\%) & - & - & - & - & - & 13.65 \\
\hline
\end{tabular}

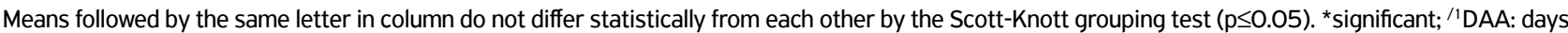
after application; ${ }^{/ 2} \mathrm{~B}$ : bispyribac-sodium = Nominee $400 \mathrm{SC}^{\circ}\left(400 \mathrm{~g} \cdot \mathrm{L}^{-1}\right) ;{ }^{2} \mathrm{M}$ : metsulfuron-methyl = Ally $\left(600 \mathrm{~g} \cdot \mathrm{kg}^{-1}\right) ;{ }^{\circ}$ polyoxyethylene alkylphenyl ether; ${ }^{/ 4}$ orange peel oil; ${ }^{15}$ mixture of lecithin and propionic acid; ${ }^{16}$ sodium lauryl ether sulphate; Fcal: $\mathrm{F}$ calculated; CV (\%): coefficient of variation. 
in grains yield when no efficient chemical or mechanical measure, respectively, were used to control the weeds under the studied conditions.

In general, it is observed that the in-tank mixture of bispyribac-sodium + metsulfuron-methyl associated with the adjuvants Iharaguen ${ }^{\mathrm{TM}}$ and Orobor $\mathrm{N} 1^{\mathrm{TM}}$ stood out regarding the globe fringerush control effectiveness in comparison to LI $700^{\text {TM }}$ and TA $35^{\text {TM }}$, with no distinction in selectivity and grains yield of irrigated rice.

\section{CONCLUSIONS}

Despite the globe fringerush (Fimbristylis miliacea) control effectiveness, by using the in-tank mixture of bispyribacsodium + metsulfuron-methyl associated with the adjuvants Iharaguen $^{\mathrm{TM}}$ and Orobor $\mathrm{N}^{\mathrm{TM}}$, has been significantly higher than the control effectiveness of LI $700^{\mathrm{Tm}}$ and TA $35^{\mathrm{Tm}}$, no significant differences were found among the treatments in selectivity and yield of grains for the rice cultivar Epagri 108.

| || | | | | | | | | | | | | | | | | | | | | | | | | | | | | | | | | | | | | | | | | | | | | | | | | | | | | | | | | | | | | | | | | | | | | | | | | | | | | | | | | | | | | | | | | | | | | | | | | | | | | | | | | | | | | | | | | | | | | | | | | | | | | | | | | | | | | | | | | | | | | | | | | | | | | | | | | | | | | | | | | | | | | | | | | | | | | | | | | | | | | | | | | | | | | | | | | | | | | | | | | | REFERENCES

ANDRES, A.; MACHADO, S.L.O. Plantas daninhas em arroz irrigado. In: GOMES, A.S.; MAGALHÃES JR., A.M. (Eds.). Arroz irrigado no Sul do Brasil. Brasília: Embrapa Informação Tecnológica, 2004. p.457-546.

CAVIGLIONE, J.H.; CARAMORI, P.H.; KIIHL, L.B; OLIVEIRA, D. Cartas climáticas do Paraná. Londrina: IAPAR, 2000. 1 CD-ROM.

CONCENÇO, G.; LOPES, N.F.; ANDRES, A.; MORAES, D.M.; SANTOS, M.Q.; RIEFFEL FILHO, J.A.; VILELLA, J.V. Controle de plantas daninhas em arroz irrigado em função de doses de herbicidas pré-emergentes e início da irrigação. Planta Daninha, Viçosa, v.24, n.2, p.303-309, 2006. DOI: 10.1590/ So $100-83582006000200013$

EMPRESA BRASILEIRA DE PESQUISA AGROPECUÁRIA (EMBRAPA). Centro Nacional de Pesquisa de Solos. Sistema brasileiro de classificação de solos. 3.ed. Rio de Janeiro: Embrapa Solos, 2013. 353p.

ERASMO, E.A.L.; PINHEIRO, L.L.A.; COSTA, N.V. Levantamento fitossociológico das comunidades de plantas infestantes em áreas de produção de arroz irrigado cultivado sob diferentes sistemas de manejo. Planta Daninha, Viçosa, v.22, n.2, p.195201, 2004. DOI: 10.1590/SO100-83582004000200004

EUROPEAN WEED RESEARCH COUNCIL (EWRC). Report of 3rd and 4th meetings of EWRC. Committee of Methods in Weed Research. Weed Research, Oxford, v.4, n.1, p.88, 1964.

FERREIRA, E.A.; CONCENÇO, G.; ASPIAZU, I.; SILVA, A.A.; GALON, L.; SILVA, A.F.; FERREIRA, F.A.; NOLDIN, J.A. Crescimento de biótipos de capim-arroz em condição de competição. Planta Daninha, Viçosa, v.26, n.4, p.799-805, 2008. DOI: 10.1590/ So $100-83582008000400011$

FLECK, N.G.; AGOSTINETTO, D.; RIZZARDI, M.A. BIANCHI, M.A.; MENEZES, V.G. Interferência de plantas concorrentes em arroz irrigado modificada por métodos culturais. Planta Daninha, Viçosa, v.22, n.1, p.19-28, 2004. DOI: 10.1590/ s0 $100-83582004000100003$

FLECK, N.G.; MENEZES, V.G.; NOLDIN, J.A.; PINTO, J.J.O.; EBERHARDT, D.S. Manejo e controle de plantas daninhas na cultura do arroz irrigado. In: VARGAS, L.; ROMAN, E.S. (Eds.) Manual de manejo e controle de plantas daninhas. Passo Fundo: Embrapa Trigo, 2008. p.329-401.
MACIEL, C.D.G.; GUERRA, N.; OLIVEIRA NETO, A.M.; POLETINE, J.P.; BASTOS, S.L.W; DIAS, N.M.S. Tensão superficial estática de misturas em tanque de glyphosate + chlorimuron-ethyl isoladas ou associadas com adjuvantes. Planta Daninha, Viçosa, v.28, n.3, p.673685, 2010. DOI: 10.1590/SO 100-83582010000300025

MARTINS, D.; CARBONARI, C.A.; TERRA, M.A.; MARCHI, S.R. Ação de adjuvantes na absorção e translocação de glyphosate em plantas de aguapé (Eichhornia crassipes). Planta Daninha, Viçosa, v.27, n.1, p.155-163, 2009. DOI: 10.1590/ So100-83582009000100020

MOREIRA, H.J.C; BRAGANÇA, H.B.N. Manual de identificação de plantas infestantes: arroz. Campinas: FMC Agricultural Products, 2010. 854p.

MILLER, P.C.H.; BUTLER ELLIS, M.C. Effects of formulation on spray nozzle performance for applications from ground-based boom sprayers. Crop Protection, Guildford, v.19, n.8-10, p.609-615, 2000. DOI: 10.1016/SO261-2194(00)00080-6

LORENZI, H. Manual de identificação e controle de plantas daninhas: plantio direto e convencional. 7th.ed. Nova Odessa: Instituto Plantarum, 2014. 383p.

ORTIZ, A.; VILLARREAL, L.; TORRES, S.; OSUNA RUIZ, M.D.; LÓPEZ, L.; FIGUEROA, R.; ZAMBRANO, C., CÁSARES, M.; FISCHER, A. Resistencia de Fimbristylis Miliacea al herbicida pirazosulfurón-etilo en campos de arroz del estado Guárico-Venezuela. Interciencia, Caracas, v.37, n.3, p.209-214, 2012.

QUEIROZ, A.A.; MARTINS, J.A.S.; CUNHA, J.P.A.R. Adjuvantes e qualidade da água na aplicação de agrotóxicos. Bioscience Journal, Uberlândia, v.24, n.4, p.8-19, 2008.

RYCKAERT, B.; SPANOGHE, P.; HAESAERT, G.; HEREMANS, B.; ISEBAERT, S.; STEURBAUT, W. Quantitative determination of the influence of adjuvants on foliar fungicide residues. Crop Protection, Guildford, v.26, n.10, p.1589-1594, 2007.

SANCHOTENE, D.M.; DORNELLES, S.H.B.; DEBORTOLI, M.P.; CAPITANIO, J.R.; MEZZOMO, R.F.; GONÇALVES, R.A. Influência de sais e do $\mathrm{pH}$ da água na eficiência de imazethapyr + imazapic no controle de arroz-vermelho. Planta Daninha, Viçosa, v.25, n.2, p.415419, 2007. DOI: 10.1590/SO100-83582007000200023 
SCHAEDLER, C.E.; NOLDIN, J.A.; EBERHARDT, D.S.; AGOSTINETTO, D.; BURGOS, N.R. Globe fringerush (Fimbristylis miliacea) cross resistance to ALS-inhibitor herbicides under field conditions in irrigated rice in the south of Brazil. Planta Daninha, Viçosa, v.31, n.4, p.893-902, 2013.

SCHONS, R.F. Assistência técnica e promoção comercial da linha de produtos Ihara na cultura do arroz irrigado. 2009. 60f. Trabalho de Conclusão de Curso (Graduação) - Centro de Ciências Agrárias, Universidade Federal de Santa Catarina, Florianópolis, 2009.

SCOTT, A.J.; KNOTT, M.A. A cluster analysis method for grouping means in the analysis of variance. Biometrics, v.30, n.3, p.507-512, 1974.

SOCIEDADE SUL-BRASILEIRA DE ARROZ IRRIGADO (SOSBAI). Arroz irrigado: recomendações técnicas da pesquisa para o Sul do Brasil. Itajaí: SOSBAI/EPAGRI, 2012. 179p.
SOCIEDADE BRASILEIRA DA CIÊNCIA DAS PLANTAS DANINHAS (SBCPD). Procedimentos para instalação, avaliação e análise de experimentos com herbicidas. Londrina: SBCPD, 1995. 42p.

VARGAS, L.; ROMAN, E.S. Conceitos e aplicações dos adjuvantes. Passo Fundo: Embrapa Trigo, 2006. 10 p. (Embrapa Trigo. Documentos Online, 56). Available from: <http://www.cnpt. embrapa.br/biblio/do/p_do56_r.htm>. Accessed on: 20 dez. 2014.

VASCONCELOS, M.C.C.; SILVA, A.F.A.; LIMA, R.S. Interferência de plantas daninhas sobre plantas cultivadas. Agropecuária Científica no Semi-Árido, Patos, v.8, n.1, p. 1-6, 2012. 